\title{
THE SOCIAL COMPONENT OF THE COMMUNITY JUSTICE REFORM
}

\author{
Emilian M. Dobrescu ${ }^{1}$ \\ Tiberiu-Viorel Popescu ${ }^{2}$
}

\begin{abstract}
The European Convention on Human Rights established an unprecedented system of protection of individual rights and freedoms applicable in the present, in almost all European countries.

The creation of a Permanent Court in 1988, was motivated essentially by the increasing the number of individual complaints the settlement of which was not possible under the old procedure. The number of individual complaints continued to increase on an accelerated rhythm and therefore the number of cases in which settlement was required has increased considerably.

The growing number of individual applications impose Community Justice System permanent reform and consideration of issues raised in the findings of this paper.
\end{abstract}

Keywords: community justice reform, European citizenship, European Court of Human Rights.

JEL Codes: H80, J18, K10.

\section{Introduction}

If short and long term measures will not be timely taken, and if the urgently needed resources will not be made available for the ECHR, the Court and the whole Convention's system will face a crisis. The provision of sufficient human and financial resources will help improve the worrying situation for short term. Adapting the working methods and procedures of the Court will also constitute an important contribution to such improvement. At the same time, broadening the direct application of Court's case law by the courts of Member States, and the inclusion of this case law in the domestic legislations of countries that are part of the Council of Europe will be likely to contribute to significant reduction of appeals lodged in Strasbourg.

On January 26, 2007, the European Court of Human Rights, reported that it received in 2006, 50,500 complaints, compared to 45,500 in 2005. We, the Romanians are on second place in Europe after Russians in terms of number of requests addressed to the European Court of Human Rights in Strasbourg. Thus, from the more than 110,000 requests in the Court's cause list in 2008, over 10 percent belong to Romanian citizens, claiming various violations of the European Convention on Human Rights, most often the property right infringement. Out of the 46 countries that have ratified the Convention, Russia is ranking number one in terms of requests sent to the ECHR. Over 90 percent of the claims are inadmissible, and the number of solutions given in the plaintiff's favor is small. Thus, from November 1, 1998 and until 2006, the ECHR ruled against Romania about 4,500 solutions, out of which 186 sentences in which it finds violations of the European Convention on Human Rights, most of them regarding the right to a fair trial, protection of property, freedom of expression, but also torture or inhuman or degrading treatments. Statistically, the most complaints against Romania, resulting in a decision favorable to plaintiff, refer to the right to a fair trial (129) and property rights (96). The trend continued also in 2007, when the ECHR found 13 violations of the right to a fair trial and 22 violations and in terms of property right.. In terms of reasons for the complaints filed with the ECHR, Romania follows the

\footnotetext{
${ }^{1}$ Romanian Academy, Romania, e-mail: dobescu@acad.ro

${ }^{2}$ Institute for Legal Research, Bucharest, Romania
} 
Russian "model": the most solutions given against Russia concern the right to a fair trial (115 between 1998 and 2006) and the right to property (101 in the same period).

Whatever measures will be taken, they should not, under any circumstances, compromise, impede or restrict the free exercise of the rights of individual complaint; the whole system of "filtering" may only exist at the Court's level, in compliance with its Regulation and under the full responsibility of its judges. According to Recommendation no. 1535/2001 of the Parliamentary Assembly of the Council of Europe (PACE), it appreciates the energetic measures taken by the European Court of Human Rights itself and the Committee of Ministers to cope with the situation, with respect to the decision to establishing the evaluation Group charged to study possible means for ensuring the effectiveness of the ECHR. Also, the Committee of Ministers must: a) reaffirm the central role and vocation of the ECHR in relation to all the national and international legal systems of Europe in maintaining a stable democratic society, in the continuity of the rule of law and observance of the human rights, and the indispensable role of the European Court of Human Rights as ultimate guarantor of the Convention; b) express the political determination of the Member States of the Council of Europe in ensuring the effectiveness of this unparalleled instrument, providing the necessary financial resources and ensuring that the decisions of the Court be implemented as appropriate; c) make available, as soon as possible, in the context of realizing the conclusions of the evaluation Group, which will have to be sent to members of PACE, the human and other resources necessary to ensure, for short term and long term, the effectiveness of the ECHR, including by the allocation of additional space in Strasbourg; d) ensure that, separately addressing the additional needs of the Convention system, the ECHR included, and taking into account the criteria of the Committee of Ministers in adopting the EC's overall budget, the Court's additional needs can be met without encumbering the budget meant for other activities of the Council of Europe; e) employ preliminary actions with all stakeholders in order to develop an amendment protocol to the European Convention on Human Rights for the purpose of ensuring the long-term effectiveness of the ECHR.

\section{Important steps in the reform of the Community Justice}

In 2004 the Regulation 2157/2001 on the European Company entered into force, which aims to establish a legal framework in order to allow the companies incorporated in different Member States to merge or to form joint holdings and subsidiaries in a faster manner, avoiding the obstacles inherent to different national legal systems in the EU. The application of this regulation is closely linked to the Directive 2001/86 on supplementing the Statute of the European Company in regard to the involvement of workers (European Society can not be registered unless it complies with the Directive). Specifically, four cases are provided for the establishment of an European Company: 1. the merger of two joint stock (anonymous) companies, having their registered office and the central administration within the Community, where at least two of them are governed by the law of different Member States; 2. setting up a holding company at the initiative of limited liability companies or limited liability, having their registered office and the central administration in the community territory, and which are located in at least two different Member States or which hold since at least two years a subsidiary governed by the law of another Member State or a branch situated in another Member State; 3. setting up a joint subsidiary by companies having their registered office and the central administration in the community territory, and which are located in at least two different Member States or which hold since at least two years a subsidiary governed by the law of another Member State or a branch situated in another Member State; 4. opportunity given to a limited liability company, which has a subsidiary in another Member State for at least two years to transform itself in an European Society.

In principle, the minimum registered capital is of EUR 120,000. Although they are published in the OJEU (Official Journal of the European Community), the registration, dissolution, liquidation remain subject to national law. In fiscal matters, also, the rules of the state where the 
head office is located shall apply. In the future, to change this situation is desired - i.e. the taxation should be made directly to the European level and thus create a new resource budget. The establishment as an European Society enables the transfer of the registered office from one EU member state to another member state and ensures a certain uniformity of administrative rules, accounting rules and staff's participation rules.

On September 27, 2005, the European Commission (EC) presented its initiative before the European Parliament on the reform of EU rules. Commission's goal is to facilitate firms' business by removing a legislative burden that is not justified, following as such to increase the competitiveness and job number, namely the new main objective of the revised Lisbon Strategy. Community Executive examined 183 proposals forwarded prior of January 1, 2004. The used criteria were: the impact of legislation on competition, the speed with which the framework of the legislative process changed, as well as their relevance in the current economic, social and political context. Of 183 proposals under consideration, the Commission decided to withdraw 68 legislative proposals, namely 31 percent of those under consideration. Five proposals will be retained but they will be subject to a rigorous impact analysis. From among the disputed directives, we quote: Directive on optical radiation that provides for workers' protection against sunlight, the directive by which the granting of the same salary and conditions to the temporary workers as for the permanent personnel is desired etc..

According to Gunter Verheugen, former European Commissioner for Industry, the Commission intends to review all the Community legislation, a huge work if we consider that it consists of more than 20,000 documents. The criteria on which this operation will rely follow to be communicated. Among the first regulations that were revised there are the ones related to the automotive industry, the waste management and the constructions. The Commission wishes that in future more stringent standards in the formulation of regulations should be implemented, especially by analyzing the costs of implementation, as well as by involvement of external experts. EC is seeking to stop the trend of the Member States to add with their initiative other conditions in addition to those expressly required by Brussels. The new trend is contrary to Community axiom promoted so far, which shows that greater harmonization at the community level of the regulations of the member countries is beneficial to the EU internal market.

The Community Law is an independent legal system that takes precedence over the provisions of the national laws in the member countries. A number of key institutions are involved in implementing, monitoring, evaluation and development of this legal system: the European Parliament (EP), with its committees - the European Commission (EC), with its directorates - the Council of Ministers, specialized in the same area of responsibility - the Court of Auditors of the European Union, the European Court of Justice, the European Court of Human Rights.

The primary Community legislation (or the primary Law) includes the Treaties establishing the European Communities (1951 - Treaty aimed at establishing the European Coal and Steel Community, 1957 - Treaty on Common Market and Euratom Treaty concerning the common policy on atomic energy) and other agreements with a similar status (for example, in 1967 - the Treaty on the common agricultural policy or in 1972 - the Treaty on the European Economic Community). The primary Community legislation is the result of direct negotiations between the Governments of the Member States. These agreements are put on paper in the form of treaties, which must then be ratified by national parliaments of member countries. The same procedure applies to any subsequent amendments to the Treaties.

The treaties establishing the European Communities have been revised and enlarged several times: in 1987 - the Single European Act, in 1992 - the Treaty on European Union, named after the place of signature, a village in the Netherlands - the Treaty of Maastricht; in 1997 - Treaty of Amsterdam, which entered into force on 1 May 1999; in 2000 - Treaty of Nice. These Treaties define the roles and obligations of the EU institutions and of the institutions involved in the decision making process, as well as the legislative, executive and legal procedures that belong to the 
Community law and its implementation.

The secondary legislation is founded on the Treaties and implies a variety of procedures defined therein. Within the Treaties that established the European Communities, and then the European Union, the Community law may take the following forms:

- Regulations, which are directly applicable and binding on all the Member States, without the need for national implementing measures.

- Directives, which are binding on the Member States with respect to the objectives to be achieved in a given time frame, leaving to the national authorities the choice of form and means of implementation. The directives must be transposed into national law in accordance with the procedures of each Member State.

- Decisions, which are fully binding for all those whom they are addressed. Decisions do not require transposition into national law. A decision may be addressed to one or all Member States, to enterprises or individuals.

- Recommendations and opinions, which are not binding.

\section{Essential deviations from the Community Justice Reform}

The European Community law currently registers in at least four types of situations in which some member states are more equal than the others in its observance:

1. France avoids transposition into the national law of the Directive on mutual recognition of professional qualifications for certain trades. This transposition had to happen in 2002 and even though the deadline has been exceeded, and the EC's warnings were stepped up, France remains firm on its positions: the recognition of professional training of nurses, social workers, firefighters and insurance agents remains with the French authorities. The Frenchmen, however, enjoy the benefits of the Directive, if they decide to practice these profession in any other member country, because the relevant country applies the EC's (mandatory - sic!) directives. The EC's authority in this situation is all the more questionable in this situation, as there is a decision of the European Court of Justice obliging France to adopt and enforce the above-mentioned European directive.

2. Italy delays the adoption of the Directive on regulating the activities and control of institutions involved in running occupational pension schemes. In the absence of the Directive to be adopted, the citizen who, although he pays taxes for decades in Italy, may find that his retirement pension is less in this country than if he would have received it in Germany or Spain, for example, under the same contractual conditions.

3. Observance of the intellectual and industrial property rights, a subject on the agenda when it comes to countries like Romania, does not enjoy the same attention when Member States are Belgium, France, Germany or the Netherlands. All these countries are late since 2003 in adopting the directive in the field.

4. The binding European regulations on public procurement transparency do not enjoy attention in countries such as Germany, Belgium, Sweden and Portugal.

The Nice Treaty was adopted for EU institutional reform so as to cope with the Union's enlargement. But, the Treaty provides for a maximum of 27 members. The EC President, Jose Manuel Barroso, said that, after the accession of Romania and Bulgaria to the EU, the enlargement process will not be blocked because of failure to adopt the European Constitution: "There is a misunderstanding. We do not believe that under the Nice Treaty wer can not have new members", said Barroso, adding the fact that the EC Treaty provides for the review of the EC's organization after the EU reaches 27 members. Not the same is the opinion of the EP, which adopted on January 19, 2006, the Duff-Voggenhuber report, according to which "it is not possible an UE's enlargement after Romania and Bulgaria accession, based on the Treaty of Nice."

But the Nice Treaty does not provide the number of MPs or the weight of vote for new EU members, beyond the number 27. These new provisions could be included in the respective 
countries' accession treaties, but this will be very difficult without a further reform of EU institutions. Ex-Commissioner for Enlargement, Olli Rehn, in May, 2006 argued that institutional reform is needed to receive new members into the Union, over the number 27. Krisztina Nagy, his spokesman said: "Commissioner Rehn has never said that it is impossible for the EU to expand further in the absence of the Constitution. He has always maintained that the EU needs better rules, as soon as possible and for the purpose of its own wellbeing". Ex-Commissioner Rehn told in the French parliament that the next country to join the EU could be Croatia, but at a date that would coincide with the possible solving pf the problem regarding the current Reform Treaty, the former Treaty establishing a Constitution for the EU.

\section{Romania's position and conclusions}

As an EU member, Romania is obliged to notify the European Commission, the measures taken in order to transpose the provisions of the community directives in force. The European Affairs Department has prepared a National Program for Implementation and Notification of Directives. On October 8, 2007, the European Commission assessed for our country, a transposition deficit of EU directives of about 0.37 percent (versus 2.8 percent, as recorded in July 2007), there being a lack of notification of the transposing measures for a number of 185 directives. This represents a transposition deficit, which is the average score across all Member States. However, the pre-litigation stage was initiated of the action for failure to fulfill obligations arising from the Treaty establishing the European Community. The motivated advisory opinion is the last procedural step before the Romanian state to be brought to the Court of Justice.

The community justice reform consists of the simple fact, whether the generic European citizen - a rather abstract concept - understands and applies after 2010, the European Union Reform Treaty, among so many rules for large and small Member States of the EU.

The Community justice has 3 piers: the European institutions system, the EU treaties system and the permanent reform of the justice system. The main characteristics of the Community justice are: presence of oversized institutions, bushy and complicated treaties, a very large legislation - over 80,000 pages of community acquis, impossible to be implemented in the member states starting from these dimensions. We suggest: a) the operation and composition of the community institutions to be simplified; b) a very simple European Constitution, modeled after the U.S. Constitution, to be elaborated, and c) programs and applications for knowing, understanding and developing by all the citizens of the EU Member States of the "European citizenship" concept to be developed.

\section{References}

1. Dobrescu E. M., 2008. Finanțare de la UE pentru promovarea cetățeniei active, Ziarul Financiarul, 21 iulie 2008.

2. Dobrescu E. M., 2009. Uniunea Europeană, un proiect în plină derulare, Ziarul Financiarul, 8 aprilie 2009

3. Dobrescu, E. M., Popescu T. V., 2010. A New Educational Model for Criminality Prevention, in "International Workshop on Economics, Management and Marketing" (ICMEA 2010), fourth edition, October 8-9, 2010, Alba Iulia, România, pp. 31-36.

4. Dobrescu E. M., Sima E., 2010. Principles of a New Model for education in the Knowledge Society, LESIJ-Lex Scientia International Journal in the Knowledge Society, nr. XVII, vo2. 2,2010 .

5. ***, Justiţie şi afaceri interne, seria Micromonografii - Politici europene, Institutul European din România, Bucureşti, 2005

6. ***, Reforma justiției sau a mentalității oamenilor, în Newsleterul Institutului de Reforme Penale, 13 martie 2007 